\title{
The involvement of anti-neurofascin 155 antibodies in central and peripheral demyelinating diseases
}

\author{
Marcus Vinicius Magno Goncalves'1, Yara Dadalti Fragoso² \\ 'Department of Neurology, Universidade da Regiao de Joinville, Joinville, SC 89219-710, Brazil. \\ ${ }^{2}$ Universidade Metropolitana de Santos, MS \& Headache Research, Santos, SP 11045-002, Brazil.
}

Correspondence to: Dr. Yara Dadalti Fragoso, Department of Neurology, Medical School, UNIMES, Avenida Conselheiro Nebias 536, Santos, SP 11045-002, Brazil. E-mail: yara@bsnet.com.br

How to cite this article: Goncalves MVM, Fragoso YD. The involvement of anti-neurofascin 155 antibodies in central and peripheral demyelinating diseases. Neuroimmuno/ Neuroinflammation 2019;6:6. http://dx.doi.org/10.20517/2347-8659.2019.08

Received: 16 Feb 2019 Accepted: 28 Feb 2019 Published: 8 Apr 2019

Science Editor: Athanassios P. Kyritsis Copy Editor: Cai-Hong Wang Production Editor: Huan-Liang Wu

The immunological aspects of autoantibodies directed against paranodal and nodal proteins form a prominent field of research. Contactin-1 and contactin-1 associated protein, gliomedin and neurofascin (NF) are Ranvier node-related proteins ${ }^{[1,2]}$. Antibodies against these proteins have been identified in chronic demyelinating conditions, such as multiple sclerosis (MS) and chronic inflammatory demyelinating polyradiculoneuropathy (CIDP); and in acute demyelinating diseases such as Guillain-Barre syndrome ${ }^{[3,4]}$. Myelin and the paranodal axoglial junctions flanking the nodes of Ranvier are not merely passive transmitters of electric signals: instead, they have essential roles in maintaining the structural integrity of myelin-axolemmal interactions, bidirectional signaling and regulation of ion channels ${ }^{[5]}$.

Here, we will focus on NF155, a major constituent of the Ranvier paranodal junction ${ }^{[6]}$. NF155 belongs to the L1 family of transmembrane cell adhesion molecules [Figure 1], typically presenting an evolutionary well-conserved protein domain structure with six immunoglobulin and five fibronectin type III domains, a transmembrane domain and a cytoplasmic domain with 113 amino acids ${ }^{[7,8]}$. It is expressed at paranodes by terminal loops of myelin ${ }^{[9]}$ and its main function is to stabilize these paranodes. Other isoforms of NFs (NF166, NF180 and NF186) are equally involved in dynamic mechanisms of synaptic stabilization, neural outgrowth and clustering of sodium channels ${ }^{[7]}$.

Patients with CIDP who present antibodies against NF155 have a particular disease course that involves onset at younger age, tremors, ataxia, dysarthria, nystagmus, extremely high protein levels in spinal fluid, symmetrical spinal root and plexus hypertrophy ${ }^{[10,11]}$. In addition, over $70 \%$ of these patients can have abnormal visual-evoked potentials during the course of CIDP $^{[10]}$. CIDP patients with anti-NF155 antibodies

(c) The Author(s) 2019. Open Access This article is licensed under a Creative Commons Attribution 4.0 International License (https://creativecommons.org/licenses/by/4.0/), which permits unrestricted use, sharing, adaptation, distribution and reproduction in any medium or format, for any purpose, even commercially, as long as you give appropriate credit to the original author(s) and the source, provide a link to the Creative Commons license, and indicate if changes were made.

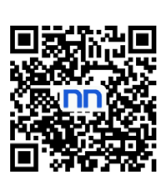



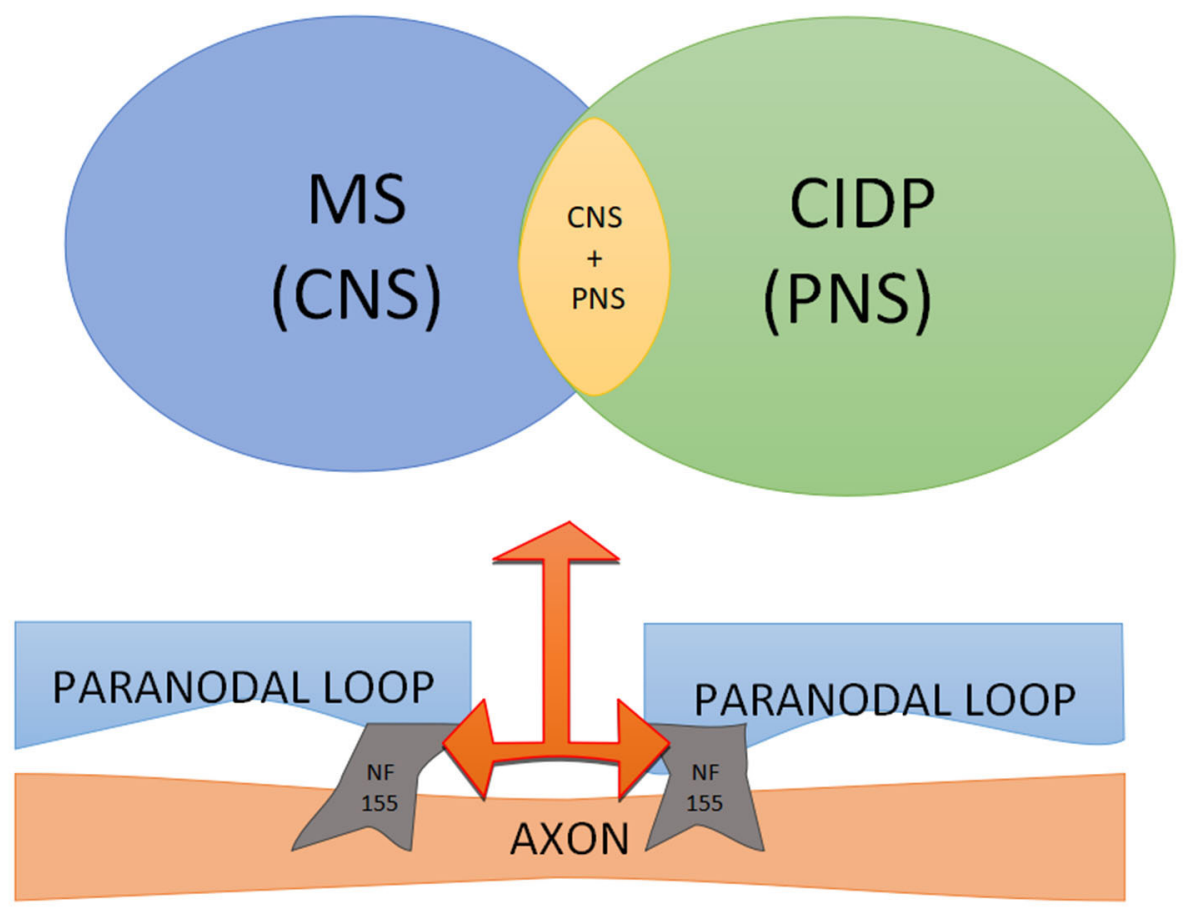

Figure 1. Neurofascin 155 (NF155) is a transmembrane adhesion molecule located in the paranodal region in the central (CNS) and peripheral nervous system (PNS), justifying the various clinical presentations. CIDP: chronic inflammatory demyelinating polyradiculoneuropathy; MS: multiple sclerosis

may present demyelinating lesions in the central nervous system, along with a remarkably poor response to intravenous courses of immunoglobulin ${ }^{[12]}$. Overall, patients with CIDP with overlapping central and peripheral demyelination associated with presence of anti-NF155 antibodies exhibit greater disability.

In addition to the peculiarities of peripheral demyelination associated with presence of NF155 antibodies, diseases of the central nervous system also show particular features when anti-NF155 antibodies are identified. Ten percent of patients fulfilling the diagnostic criteria for $\mathrm{MS}^{[13]}$, may have antibodies against $\mathrm{NF} 155^{[14]}$. Cases of neurological disease with onset typical of MS that were subsequently diagnosed as CIDP have been described ${ }^{[15-17]}$. Interestingly, presence of antibodies against NF155 is significantly more frequent in patients with primary progressive forms of MS than in those with relapsing disease ${ }^{[18]}$.

Patients who develop antibodies against NF155 may ultimately present a different form of demyelinating disease with both central and peripheral involvement. There are often signs of cerebellar, spinal root and plexus involvement, optic nerve demyelination and high levels of protein in the spinal fluid in these cases. Anti-NF155 antibodies may form a biomarker for a particular form of demyelinating neurological disease. NF155 does not activate a complement ${ }^{[9]}$. Therefore, at least in theory, patients with anti-NF155 antibodies might respond well to therapies using ocrelizumab and rituximab. "Anti-NF155 demyelination" may be a different disease with peculiar presentation and therapeutic management.

\section{DECLARATIONS}

\section{Authors' contributions}

Made substantial contributions to conception of the study, as well as provided administrative, technical, and material support: Goncalves MVM, Fragoso YD

\section{Availability of data and materials}

Not applicable. 


\section{Financial support and sponsorship}

None.

\section{Conflicts of interest}

Both authors declared that there are no conflicts of interest.

\section{Ethical approval and consent to participate}

Not applicable.

\section{Consent for publication}

Not applicable.

\section{Copyright}

(c) The Author(s) 2019.

\section{REFERENCES}

1. Ogata H, Yamasaki R, Hiwatashi A, Oka N, Kawamura N, et al. Characterization of IgG4 anti-neurofascin 155 antibody-positive polyneuropathy. Ann Clin Transl Neurol 2015;2:960-71.

2. Stathopoulos P, Alexopoulos H, Dalakas MC. Autoimmune antigenic targets at the node of Ranvier in demyelinating disorders. Nat Rev Neurol 2015;11:143-56.

3. Querol L, Siles AM, Alba-Rovira R, Jauregui A, Devaux J, et al. Antibodies against peripheral nerve antigens in chronic inflammatory demyelinating polyradiculoneuropathy. Sci Rep 2017;7:14411.

4. Kira JI, Yamasaki R, Ogata H. Anti-neurofascin autoantibody and demyelination. Neurochem Int 2018; doi: 10.1016/ j.neuint.2018.12.011.

5. Schafer DP, Bansal R, Hedstrom KL, Pfeiffer SE, Rasband MN. Does paranode formation and maintenance require partitioning of neurofascin 155 into lipid rafts? J Neurosci 2004;24:3176-85.

6. Illa I. Arthur asbury lecture: chronic inflammatory demyelinating polyradiculoneuropathy: clinical aspects and new animal models of auto-immunity to nodal components. J Peripher Nerv Syst 2017;22:418-24.

7. Kriebel M, Wuchter J, Trinks S, Volkmer H. Neurofascin: a switch between neuronal plasticity and stability. Int J Biochem Cell Biol 2012;44:694-7.

8. Hortsch M, Nagaraj K, Mualla R. The L1 family of cell adhesion molecules: a sickening number of mutations and protein functions. Adv Neurobiol 2014;8:195-229.

9. Pomicter AD, Shroff SM, Fuss B, Sato-Bigbee C, Brophy PJ, et al. Novel forms of neurofascin 155 in the central nervous system: alterations in paranodal disruption models and multiple sclerosis. Brain 2010;133:389-405.

10. Ogata H, Matsuse D, Yamasaki R, Kawamura N, Matsushita T, et al. A nationwide survey of combined central and peripheral demyelination in Japan. J Neurol Neurosurg Psychiatry 2016;87:29-36.

11. Bailly L, Mongin M, Delorme C, Apartis E, Saheb S, et al. Tremor associated with chronic inflammatory demyelinating polyneuropathy and anti-neurofascin-155 antibodies. Tremor Other Hyperkinet Mov (N Y) 2018;8:606.

12. Devaux JJ, Miura Y, Fukami Y, Inoue T, Manso C, et al. Neurofascin-155 IgG4 in chronic inflammatory demyelinating polyneuropathy. Neurology 2016;86:800-7

13. Polman CH, Reingold SC, Banwell B, Clanet M, Cohen JA, et al. Diagnostic criteria for multiple sclerosis: 2010 revisions to the McDonald criteria. Ann Neurol 2011;69:292-302.

14. Kawamura N, Yamasaki R, Yonekawa T, Matsushita T, Kusunoki S, et al. Anti-neurofascin antibody in patients with combined central and peripheral demyelination. Neurology 2013;81:714-22.

15. Klehmet J, Staudt M, Diederich JM, Siebert E, Meinl E, et al. Neurofascin (NF)155- and NF186-specific T cell response in a patient developing a central pontocerebellar demyelination after 10 years of CIDP. Front Neurol 2017;8:724

16. Shimizu M, Koda T, Nakatsuji Y, Ogata H, Kira JI, et al. A case of anti-neurofascin 155 antibody-positive combined central and peripheral demyelination successfully treated with plasma exchange. Rinsho Shinkeigaku 2017;57:41-4.

17. Itaya $\mathrm{K}$, Inoue $\mathrm{M}$, Iizuka N, Shimizu $\mathrm{Y}$, Yuki N, et al. A case of a 17-year-old male with neurofascin-155 antibody-positive chronic inflammatory demyelinating polyradiculoneuropathy presenting with tremor and ataxia. Rinsho Shinkeigaku 2016;56:633-6.

18. Stich O, Perera S, Berger B, Jarius S, Wildemann B, et al. Prevalence of neurofascin-155 antibodies in patients with multiple sclerosis. J Neurol Sci 2016;364:29-32. 